\title{
Satisfaction level of phisicians working in a social health organization of unified health system in brazil
}

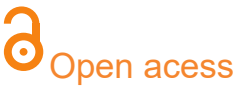

${ }^{1}$ Laboratório de Análises Clínicas da Faculdade de Medicina do ABC

${ }^{2}$ Ciências Médicas da PUC, $R$. Jouberte Wey

${ }^{3}$ Departamento de Ciências Biológicas da Universidade Federal de São Paulo, UNIFESP

${ }^{4}$ Ministério da Saúde de Angola

\section{Corresponding author:} profferfonseca@gmail.com

Manuscript received: September 2017 Manuscript accepted: November 2017 Version of record online: December 2017
Fabio Pegorari', Flávio Morgado², Beatriz da Costa Aguiar Alves $^{1}$, Ligia Ajaime Azzalis ${ }^{3}$, Virginia Berlanga Campos Junqueira ${ }^{3}$, Maria Teresa André Vicente $^{4}$, Fernando Luiz Affonso Fonseca ${ }^{1}$

\begin{abstract}
Introduction: The evaluation of a work system is based on the ability to adapt work to the man and the man to the work. One of the aspects that interfere in the capacity of adaptation is the satisfaction in the work as the integration, the autonomy, the motivation, the involvement and the utilization of the physical and mental capacities.
\end{abstract}

Objective: To analyze the level of satisfaction of medical professionals regar ding their work environment in a Social Health Organization of Brazilian Unified Health System.

Methods: It is a cross-sectional, exploratory and descriptive study. For data collection, we used a questionnaire mailed through the Google Docs platform, containing 36 questions about indicators: material, personnel, quality and social.

Results: A total of 51 physicians participated in the study. The findings showed significant associations between their satisfaction of work environment and relationship with their work team, unit manager and performance recognition.

Conclusion: The satisfaction in the work environment of the medical professional in the Social Health Organization is associated with internal factors, as well as the need for their performance recognition by the management policy. The external factors studied, such as multiple job sites.

Keywords: satisfaction, work environment, social organization of health, doctor 


\section{INTRODUCTION}

The evaluation of a work system is based on the adaptability of work to man and man to work $^{1,2}$. One of the aspects that interfere in the adaptive capacity is the satisfaction in the work as the integration, the autonomy, the motivation, the involvement and the utilization of the physical and mental capacities ${ }^{3}$.

Job satisfaction is defined as the result of the employee's assessment of their work and the achievement of their values through this activity, and is a positive emotion of well-being. These needs for survival and feeling good are common to all, but values differ from people ${ }^{4}$.

The concept of satisfaction at work is given to a general attitude of a person in relation to their work, involving their relations in the place, even the relations of power; the environment; the organization of work; the company's management policies; their technologies; goals, objectives and interests; its economic-financial environment; its history and the desires of the employees from the individual and collective perspective ${ }^{5}$.

The expression satisfaction comes from the judgment of an individual between his job and his profession. Satisfaction with life implies contentment or acceptance on the part of individuals and the conditions of their existence that is associated with the way they perceive the fulfilment of what they desire or need. Perceived inequality can contribute substantially to professional dissatisfaction ${ }^{6}$.

The phrase "happy employees are more productive employees" is usually true. This speculation began in the 1930s and 1940s, mainly due to the contribution of Hawthorne's research-oriented studies of the Western Electric company. From those results managers began to focus on the conditions and work environment to make their employees happier. In the 1980s, some authors reviewed the analysis of this research by labelling it as 'illusory' because it indicated that the relationship between job satisfaction and performance was not considerably high. More recently, however, more than 300 studies have been done on this same analysis, correcting errors from the previous review and thus instigating the correlation of satisfaction and performance at work as reasonably high ${ }^{7}$.

For successful businesses it has become essential to make the work environment a pleasant place as it makes interpersonal relationships easier and improves productivity. It also reduces accidents, illness, absenteeism and staff turnover ${ }^{8}$.

Working involves relationships, which can lead to satisfaction or can cause suffering. Healthcare jobs are special and involve human care, executed mostly in the

\section{METHODS}

It is a cross-sectional, prospective, exploratory and descriptive study. Having as focus an OSS located in São Paulo, Brazil. A questionnaire regarding the work satisfaction of doctors, applied by electronic address, was used as basis for data analysis. The same was composed of 36 questions, mailed to phisicians $(n=64)$ of different specialties. The questions were divided with the indicators as follows: material, personnel, quality and social. form of collective work. Such work implies relationships between healthcare professionals and users of services and their families, as well as in relationships between team members and between professionals and managers ${ }^{8,9}$.

A study on the moderating effects of job satisfaction and the motivation of physicians to adhere to clinical practice guidelines reports that dissatisfied professionals were less willing to adhere to the guidelines when working under social pressures to comply with them, in counterpoint to satisfied physicians. The professional satisfaction of physicians can help in the identification and elaboration of interventions if they are satisfied with their practice ${ }^{10}$.

Over the last two decades of the last century, there has been an intense debate about the state's fiscal crisis, its implications for the process of financing public policies, and possible alternatives to the problem. At the limit, this debate expressed the confrontation between conceptions about the role of the State and the patterns of intervention on society. From the debate begun in the 1990s in Brazil, regarding the need for a given state restructuring, a great amount of energy and theoretical production was mobilized in relation to the theme ${ }^{11}$.

In Brazil, the concrete expression of this debate is represented in the Director Plan for Reform of the State Apparatus (PDRAE), proposed by the Ministry of Administration and State Reform (MARE) of the FHC government ${ }^{12}$

In State of São Paulo, there was an option to experiment with a new management model for some of its hospitals, with the implementation of Social Health Organizations (SHOs), managed by non-state public entities, subject to management contracts, which are monitored and evaluated by the structure of the State Health Secretariat, created specifically for this purpose ${ }^{13}$.

SHOs are defined as entities of interest and public interest, non-profit associations, arising from the qualification of legal entities under private law, in teaching activities, technological research, technological development, protection and preservation of the environment ${ }^{14,15}$.

It has been observed the satisfaction of physicians in the work environment in a Social Health Organization can contribute to qualified care, allowing a lower index of adverse events to the patients' health.

Thus, the objective of this study is to analyse the level of satisfaction of medical professionals regarding their work environment in a social health organization in Brazil.

Data collection was performed through the application of a questionnaire, sent to medical professionals through the Google Docs platform. This instrument consists of questions about medical satisfaction in the workplace, with the options for "agree", "disagree", "neither agree nor disagree" answers. Emails were sent to $(n=64)$ physicians for eight attempts. After the eighth attempt without answers, the professionals who did not respond were excluded, 
and there were therefore 13 sample losses. Contact with professionals occurred from April 2014 to July 2016.

The descriptive statistical analysis was presented with results in tables in absolute and relative frequency, associating the satisfaction of the medical professional

\section{RESULTS}

A total of 51 physicians linked to OSS participated in the study. After the data were collected, the tabulation was performed and five tables with specific descriptions according to the work time, number of workplaces, relationship with the team and management of the Health Unit and their professional recognition, was used the chisquare test, and for all the analyses was used a confidence level of 95\%, using Stata statistical software version 11.0.

and the main results of the research were presented (Table 1, Table 2, Table 3, Table 4 and Table 5).

Table 1: Characterization Doctors who make up the staff of the Social Health Organization (OSS) of the city of Santo André, São Paulo, Brazil, 2017

\begin{tabular}{lcc}
\hline Variables & $\mathbf{N}$ & $\%$ \\
\hline Sex & 25 & 49,1 \\
Male & 26 & 50,9 \\
Female & & \\
Age groups & 3 & 5,9 \\
20 - 29 years & 26 & 51,0 \\
30 - 39 years & 12 & 23,5 \\
40 - 49 years & 3 & 5,9 \\
50 - 59 years & 7 & 13,7 \\
More than 60 years & & \\
Marital status & 30 & 58,9 \\
Married & 17 & 33,3 \\
Single & 2 & 3,9 \\
Divorced & 2 & 3,9 \\
Consensus Union & & 52,9 \\
Number of children & 27 & 39,3 \\
Non & 20 & 7,8 \\
1 or 2 children & 4 & 21,6 \\
3 or 4 children & & 58,8 \\
Neutrality & 11 & 15,7 \\
Interior of São Paulo & 30 & 3,9 \\
São Paulo Municipality & 8 & 98,0 \\
Other States & 2 & \\
Other Countries & & \\
Means of Transport & 1 & \\
Subway & 50 & \\
Car & & \\
\hline
\end{tabular}

Table 2: Characterization of the training and length of service of the Social Health Organization (SHO) of Santo André city, SP, Brazil,2017

\begin{tabular}{lll}
\hline Variables & $\mathbf{n}$ & \% \\
\hline Type of institution that attended & 12 & 23,5 \\
$\quad$ Public & 39 & 76,5 \\
Private & & \\
Period of time graduated from medicine & 1 & 2,0
\end{tabular}


5 to 14 years

56,9

15 to 24 years

25 to 34 years

More than 35 years

How long does it take you to get to work?

Less than 1 hour

27,4

30 minutes to 1 hour

From 1 hour to 1.5 hours

21,6

How long have you worked in the Health Unit?

Less than 1 hour

From 1 to 2 years

17,6

From 3 to 4 years

11,8

From 7 to 8 years

15,7

From 9 to 10 years

19,6

More than 10 years

11,8

6

23,5

What is way you are contracting in the Health Unit?

CLT

Others

How many training courses did you attend at the Health Unit?

1 to 2 courses

3 to 4 courses

5 to 6 courses

6 to 7 courses

More than 10 courses

Did you work in another Health Unit outside the ABC Region?

No

Yes

How many places do you currently work, including this $\mathrm{SHO}$ Health

2 locals

3 locals

4 or more locals

Table 3: Description of work environment satisfaction Santo André city, SP, Brazil,2017

\begin{tabular}{lcc}
\hline Variables & $\mathbf{n}$ & $\mathbf{\%}$ \\
\hline I do what I like & & \\
Agree & 47 & 92,1 \\
Disagree & 1 & 2,0 \\
$\quad$ Neither agree nor disagree & 3 & 5,9 \\
Is the training I received enough to carry out my activities? & 28 & 54,9 \\
Agree & 11 & 21,6 \\
Disagree & 12 & 23,5 \\
Neither agree nor disagree & \multicolumn{2}{c}{} \\
In the work I do, is there a lot of tension? & 36 & 70,6
\end{tabular}




\section{Disagree}

In the exercise of my activities, do you count my potential and experiences?

Agree

Disagree

Neither agree nor disagree

Does the work in the Health Unit allow me to improve my knowledge?

Agree

Disagree

Neither agree nor disagree

Does the physical environment of the unit I work in compromise my results?

Agree

Disagree

Neither agree nor disagree

Do I have the materials I need to do my job?

\section{Agree}

Disagree

Neither agree nor disagree

Are there adequate criteria and procedures for non-wastage of material?

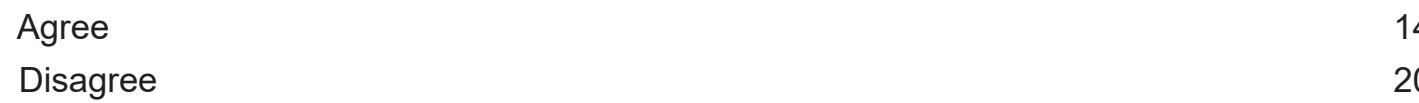

Do I consider my services to be of the necessary quality?

\section{Agree}

Disagree

I consider that the services provided by other colleagues have the necessary quality?

Agree

Disagree

Neither agree nor disagree

In my medical team is the patient well attended?

Agree

Disagree

Neither agree nor disagree

Do the professionals of the medical team discuss the difficulties encountered at work?

Agree

Disagree

Neither agree nor disagree

Do I have good relationships with teammates?

\section{Agree}

Do I have a good relationship with management?

Agree

Does the medical team hold meetings regularly among colleagues? 


\section{Disagree}

Neither agree nor disagree

Does the directorate of the Health Unit hold regular meetings with professionals?

$\begin{array}{llr}\text { Agree } & 10 & 19,6 \\ \text { Disagree } & 29 & 56,9 \\ \text { Neither agree nor disagree } & 12 & 23,5\end{array}$

Do I want to work for a long time in this Health Unit?

$\begin{array}{lcr}\text { Agree } & 34 & 66,7 \\ \text { Disagree } & 6 & 11,7 \\ \text { Neither agree nor disagree } & 11 & 21,6\end{array}$

Does the community recognize my work?

Agree

Disagree

Neither agree nor disagree

Does management recognize my job?

Agree

Disagree

Neither agree nor disagree

I believe the results of this research will be well used?

Agree

Disagree

Neither agree nor disagree

12

23,5

Table 4: Association of the satisfaction of the medical professional according to his relationship with the work team, with the management of the Health Unit and its recognition. Santo André city, SP, Brazil,2017

\begin{tabular}{lcccc}
\hline Variables & \multicolumn{3}{c}{ I do what I like } \\
\hline & Agree & Disagree & $\begin{array}{c}\text { Neither agree } \\
\text { nor disagree }\end{array}$ & $\mathrm{p}^{*}$ \\
& & $\mathrm{n}(\%)$ & & \\
I have good relationships with teammates? & $46(93,9)$ & $0(0,0)$ & $3(6,12)$ & $<0,001$ \\
$\quad$ Agree & $1(50,0)$ & $1(50,0)$ & $0(0,0)$ & \\
$\quad$ Neither agree nor disagree & & & & \\
Do I have a good relationship with management? & $41(95,3)$ & $0(0,0)$ & $2(4,7)$ & 0,005 \\
Agree & $1(50,0)$ & $0(0,0)$ & $1(50,0)$ & \\
$\quad$ Disagree & $5(83,3)$ & $1(16,7)$ & $0(0,0)$ & \\
$\quad$ Neither agree nor disagree & & & & \\
Management recognizes my job? & $30(100,0)$ & $0(0,0)$ & $0(0,0)$ & 0,037 \\
Agree & $7(70,0)$ & $1(10,0)$ & $2(20,0)$ & \\
$\quad$ Disagree & $10(90,9)$ & $0(0,0)$ & $1(9,1)$ & \\
Neither agree nor disagree & & & & \\
\hline
\end{tabular}

${ }^{*}$ Qui-square.

Table 5: Association of the satisfaction of the medical professional according to the working time and the number of places of work. Santo André city, SP, Brazil,2017

\begin{tabular}{lccc}
\hline Variables & I do what I like \\
\hline & Agree & Disagree & $\begin{array}{c}\text { Neither agree } \\
\text { nor disagree }\end{array}$ \\
& $\mathrm{n}(\%)$ & $\mathrm{p}^{*}$
\end{tabular}




\begin{tabular}{|c|c|c|c|c|}
\hline \multicolumn{5}{|c|}{ How long have you worked in the Health Unit? } \\
\hline Less than 1 year & $9(100,0)$ & $0(0,0)$ & $0(0,0)$ & \multirow[t]{6}{*}{0,729} \\
\hline From 1 to 2 years & $6(100,0)$ & $0(0,0)$ & $0(0,0)$ & \\
\hline From 3 to 4 years & $7(87,5)$ & $0(0,0)$ & $1(12,5)$ & \\
\hline From 7 to 8 years & $10(100,0)$ & $0(0,0)$ & $0(0,0)$ & \\
\hline From 9 to 10 years & $5(83,3)$ & $0(0,0)$ & $1(16,7)$ & \\
\hline More than 10 years & $10(83,3)$ & $1(8,3)$ & $1(8,3)$ & \\
\hline \multicolumn{5}{|c|}{$\begin{array}{l}\text { In how many places do you currently work, including } \\
\text { this Health Unit? }\end{array}$} \\
\hline 1 local & $5(100,0)$ & $0(0,0)$ & $0(0,0)$ & \multirow[t]{5}{*}{0,881} \\
\hline 2 locals & $6(100,0)$ & $0(0,0)$ & $0(0,0)$ & \\
\hline 3 locals & $12(85,7)$ & $1(7,1)$ & $1(7,1)$ & \\
\hline 4 or more locals & $23(92,0)$ & $0(0,0)$ & $2(8,0)$ & \\
\hline Non & $1(100,0)$ & $0(0,0)$ & $0(0,0)$ & \\
\hline
\end{tabular}

${ }^{\star}$ Qui-square.

\section{DISCUSSION}

Regarding the satisfaction of medical professionals regarding their work environments in a Social Health Organization (SHO), it was observed that there were significantly positive associations regarding the satisfaction of the professional in the relationship with the work team, management of the Health Unit and professional recognition, corroborating with studies on the satisfaction of British physicians in general practice, in which they are reported to be more satisfied with the harmonious environment and good interpersonal relationship, however dissatisfied with the lack of autonomy and use of their skills in the labor field ${ }^{16}$.

Studies carried out with medical professionals from the public sector in Belo Horizonte, Brazil, have verified that strategies to increase autonomy, about their work activities are possible fundamental actions to establish the satisfaction of these professionals ${ }^{17}$. There is ample cooperation and promotion policies with social and labor support as important conditions for medical professionals to be satisfied about their work environment.

When analyzing the most common working conditions and mental disorders in physicians in Brazil, it was verified that most of the professionals studied are more satisfied with their work environment when they are supported by the work team, which also observed in this study $^{18}$. But, on the other hand, it emphasizes that social support modulates the impact of stress on one's health and job satisfaction ${ }^{19}$.

With this, it is observed that the relations of the offered working conditions and the support of the management to the medical professional are fundamental components so that this professional has satisfaction as the performance of his profession.

It should be noted that one of the main factors that can culminate for a professional to leave the organization in which he works is his level of dissatisfaction with his duties. The relationship between physician satisfaction with work and still the turnover - inflow and outflow of personnel, cannot be fully understood without analyzing the context in which these professionals are inserted, so that factors such as cooperation, teamwork, management model, and organizational infrastructure ${ }^{18}$.

Currently one of the biggest difficulties in relation to the continuity of the medical professional to the workplace is the turnover. However, the results presented here showed significant time in the workplace, which can be related to satisfaction in labor relations. Therefore, the incentive contributes positively to reducing the high levels of dissatisfaction in the work environment ${ }^{15}$.

Encouraging the improvement of interpersonal relationships can help managers of other institutions as a way to increase the fixation of the medical professional in their work environment ${ }^{20}$.

A survey conducted by the British Medical Association with 15,560 responses from general practitioners in the UK reported that $34 \%$ of practitioners were willing to relinquish practice, reporting that they experienced high levels of work-related stress, and $16 \%$ said their stress was significant and uncontrollable ${ }^{21}$.

Prolonged periods of overwork may adversely affect the well-being of physicians, leading to manifestations of mental illness, problems in personal relationships, and depression $^{22}$. It is observed that the good interpersonal relationship and the fact that the medical professional likes his work are the main factors associated with satisfaction, as well as the tenure for more than ten years in the local health service.

There is a relationship between physician satisfaction with work, and turnover cannot be fully understood without analyzing the context in which professionals are inserted. Consideration should be given to aspects such as cooperation and teamwork, management models used and municipal infrastructure ${ }^{23}$. Even when there is an ample working day, there is a high degree of satisfaction on the part of the medical professional, as it shows a satisfactory working relationship.

Analyzing public psychiatric services teams and evaluating job satisfaction, it was possible to observe 
that employees reported greater satisfaction and quality in the service when they related well at work, in relation to participation in the service and working conditions ${ }^{24}$. It is noticed that the satisfaction monitoring is useful to improve the quality of services. It is also observed the dissatisfaction at work of foreign national physicians in Saxony - Germany, where human relations with their colleagues in the workplace, reporting less satisfaction ${ }^{25}$.

A high number of workplaces and time at work in the institution promotes the association of these variables with the satisfaction of the professionals studied in this research. The personal relationship in the work environment with other health professionals contributes to high levels of satisfaction regarding good relationships with colleagues and the support of superiors and subordinates ${ }^{26}$.

In the field of management, the contributions of this study indicate a greater observation in the interpersonal relations for an adequate training for the continuous qualification of the managers and medical professionals, as well as the relevance of the economic conjuncture of the country on the demand of jobs and shortage of practicing physicians. The scenario reinforces the importance of management in observing the aforementioned factors, as well as the sensitivity of identifying the motivating elements that can generate impacts such as the discontinuity

\section{CONCLUSION}

The study concluded that satisfaction in the work environment of the medical professional in the Social Health Organization is associated with internal factors such as the personal relationship with the manager and co-workers, as well as the need for their professional recognition by the management policy. The external factors studied, such as multiple job sites, did not corroborate the dissatisfaction. of the professional in the health service, where also the own organization generates reflexive questions for the field of public health.

This extensive analysis brings the factors influencing satisfaction in which minimum management actions, such as the professional feel recognized and supported in his work environment, as well as being heard in his inquiries and assertive questions can generate to the health service greater retention and motivation of them. In addition, it is known that job satisfaction can directly reflect the quality of the service provided and such information can be used as an important tool for health services management ${ }^{26,27}$.

Value hierarchies and so-called dynamic value characters are also points to be considered in terms of job satisfaction and dissatisfaction. They are related to the emotion and evaluation that is realized in some contexts related to the work and that even influence in the way in which these relations are discussed ${ }^{4}$.

This level of job satisfaction can affect the level of care that is directed to patients. In a large study by Xiáng et al. ${ }^{6}$, it was shown that job satisfaction associated with the fact of influencing care, primary care professionals have more satisfaction with work when compared to other professionals. Many factors, such as the development of fatigue, can be considered to influence satisfaction ${ }^{21}$.

The satisfaction in the work environment of the medical professional in the Social Health Organization is associated with internal factors, as well as the need for their performance recognition by the management policy. The external factors studied, such as multiple job sites.

\section{REFERENCES}

1. Guérin F, Kerguelen A, Laville A, Daniellou F, Duraffourg J. Compreender o trabalho para transformá-lo: a prática da ergonomia. São Paulo: Edgard Blücher; 2001.

2. Dejours C, Abdoucheli E, Jayet C. A carga psíquica do trabalho. In: Psicodinâmica do trabalho: contribuições da Escola Dejouriana à análise da relação prazer, so frimento e trabalho. 3. ed. São Paulo: Atlas; 1994. p. 21-32.

3. Fischer FM, Paraguay AIBB. A ergonomia como instrumento de pesquisa e melhoria das condições de vida e trabalho. In: Fischer FM, Gomes JR, Colaciopp S. Tópicos de saúde do trabalhador. São Paulo: Hucitec; 1989.

4. Locke EA. What is job satisfaction? Organizational Behav Hum Performance. 1969;4(4):309-36. DOI: https://doi.org/10.1016/0030-5073(69)90013-0

5. Robbins SP, Judge TA, Sobral F. Comportamento organizacional. 14. ed. São Paulo: Pearson Prentice Hall; 2010.

6. Wáng YXJ, Lǐ YT. AME survey-003 A1-part1: in current China, do you regret you joined the medical profession. Quant Imaging Med Surg. 2015;5(5):765-73.

DOI: http?;dx.doi.org/10.3978/j.issn.2223-4292.2015.10.07

7. Chiavenato I. Introdução à teoria geral da administração. 7. ed. Rio de Janeiro: Elsevier; 2011.

8. Bertoncini JH, Pires DEP, Scherer MDA. Condições de trabalho e renormalizações no trabalho das enfermeiras na saúde da família. Trab Edu Saúde. 2011;9(supl.1):157-73. DOI: https://dx.doi.org/10.1590/S1981-77462011000400008

9. Scherer MDA, Pires D, Schwartz Y. Trabalho coletivo: um desafio para a gestão em saúde. Rev Saúde Pública. 2009;43(4):721-5. DOI: http://dx.doi.org/10.1590/S0034-89102009000400020 
10. Waddimba AC, Beckman HB, Mahoney TL, Burgess Jr JF. The moderating effect of job satisfaction on physicians motivation to adhere to financially incentivized clinical practice guidelines. Med Care Res Rev. 2016;74(2):148-77. DOI: http://dx.doi.org/10.1177/1077558716628354

11. Barbosa NB, Elias PEM. As organizações sociais de saúde como forma de gestão público/privado. Ciênc Saúde Coletiva. 2010;15(5):2483-95. DOI: http://dx.doi.org/10.1590/S1413-81232010000500023

12. Petras J. Ensaios contra a ordem. São Paulo: Scritta; 1995.

13. Ibañez N, Bittar OJNV, Sá ENC, Yamamoto EK, Almeida MF, Castro CGJ. Organizações sociais de saúde: o modelo do Estado de São Paulo. Ciênc Saúde Coletiva. 2001; 6(2):391-404. DOI: http://dx.doi.org/10.1590/S1413-81232001000200009

14. Campos CVA, Malik AM. Satisfação no trabalho e rotatividade dos médicos do Programa de Saúde da Família. Rev Adm Pública. 2008;42(2):347-68. DOI: http://dx.doi.org/10.1590/S0034-76122008000200007

15. Ritsema TS, Roberts KA. Job satisfaction among British physician associates. Clin Med (Lond). 2016;16(6):511-3. DOI: http://dx.doi.org/10.7861/clinmedicine.16-6-511

16. Ribeiro RB, Assunção AA, Araújo TM. Factors associated with job satisfaction among public-sector physicians in Belo Horizonte, Brazil. Int J Health Serv. 2014;44(4):787-804. DOI: http://dx.doi.org/10.2190/HS.44.4.f

17. Assunção AA, Machado CJ, Prais HA, Araújo TM. Working conditions and common mental disorders in physicians in Brazil. Occup Med (Lond). 2013;63(3):234-7. DOI: http://dx.doi.org/10.1093/occmed/kqt009

18. Collins S. Statutory social workers: stress, job satisfaction, coping, social support and individual differences. Br J Social Work. 2007;38(6):1173-93. DOI: https://doi.org/10.1093/bjsw/bcm047.

19. Magnago $C$, Pierantoni $C$. Cenário de contratações para a Estratégia Saúde da Família no município do Rio de Janeiro: análise dos anos 2000. J Manag Prim Health Care. 2013;4(2):116-25.

20. Rimmer A. A third of GPs are considering retirement, BMA survey finds. BMJ. 2015;350:h2037. DOI: https://doi.org/10.1136/bmj.h2037

21. Wada K1, Arimatsu M, Yoshikawa T, Oda S, Taniguchi H, Higashi T, et al. Factors on working conditions and prolonged fatigue among physicians in Japan. Int Arch Occup Environ Health. 2008;82(1):59-66. DOI: https://dx.doi.org/10.1007/s00420-008-0307-3

22. Pierantoni CR, Vianna CMM, França T, Magnago C, Rodrigues MPS. Rotatividade da força de trabalho médica no Brasil. Saúde Debate. 2015;39(106):637-47. DOI: http://dx.doi.org/10.1590/0103110420151060003006

23. Ishara S, Bandeira M, Zuardi AW. Public psychiatric services: job satisfaction evaluation. Rev Bras Psiquiatr. 2008;30(1):38-41. DOI: http://dx.doi.org/10.1590/S1516-44462006005000064

24. Pantenburg B, Kitze k, Luppa M, König H, Riedel-Heller SG. Job satisfaction of foreign-national physicians working in patient care: a cross-sectional study in Saxony, Germany. J Occup Med Toxicol. 2016;11(1):41. DOI: http://dx.doi.org/10.1186/s12995-016-0129-2

25. Lu Y, Hu XM, Huang XL, Zhuang XD, Guo P, Feng LF, et al. Job satisfaction and associated factors among healthcare staff: a crosso-sectional study in Guangdong Province, China. BMJ Open. 2016;6(7):e011388. DOI: http://dx.doi.org/10.1136/bmjopen-2016-011388

26. Nabialczyk-Chalupowski M. Tracking the origins, defining and quantifying quality of care: Can we reach a consensus? J Hum Growth Dev. 2016;26(2):133-138. DOI: http://dx.doi.org/10.7322/jhgd.119237

27. Bezerra IMP, Sorpreso ICE. Concepts and movements in health promotion to guide educational practices. J Hum Growth Dev. 2016;26(1):11-20. DOI: http://dx.doi.org/10.7322/jhgd.113709 


\section{Resumo}

Introdução: A avaliação de um sistema de trabalho se dá a partir da capacidade de adaptação do trabalho ao homem e do homem ao trabalho. Um dos aspectos que interferem na capacidade de adaptação é a satisfação no trabalho como a integração, a autonomia, a motivação, o envolvimento e a utilização das capacidades físicas e mentais.

Objetivo: Analisar nível de satisfação dos profissionais médicos quanto ao seu ambiente de trabalho em Organização Social de Saúde de assistência ao sistema único de saúde do Brasil

Método: Trata-se de um estudo transversal, exploratório e descritivo. Para coleta de dados, utilizou-se um instrumento contendo 36 questões acerca dos indicadores: material, pessoal, qualidade e social, enviado por meio da plataforma Google Docs.

Resultados: Participaram da pesquisa 51 médicos. Verificou-se a existência de associações significativas entre satisfação quanto ao ambiente do trabalho do médico e relacionamento com a equipe de trabalho, gerência da unidade e reconhecimento profissional.

Conclusão: A satisfação no ambiente de trabalho do profissional médico na Organização Social de Saúde (OSS) esteve associada aos fatores internos, assim como a necessidade do seu reconhecimento profissional pela política de gestão da OSS.

Palavras-chave: satisfação, ambiente de trabalho, organização social de saúde, médico

${ }^{\odot}$ The authors (2017), this article is distributed under the terms of the Creative Commons Attribution 4.0 International License (http://creativecommons.org/licenses/by/4.0/), which permits unrestricted use, distribution, and reproduction in any medium, provided you give appropriate credit to the original author(s) and the source, provide a link to the Creative Commons license, and indicate if changes were made. The Creative Commons Public Domain Dedication waiver (http://creativecommons.org/publicdomain/ zero/1.0/) applies to the data made available in this article, unless otherwise stated. 